\title{
Family relationships in town are brokbrok: Food sharing and "contribution" in Port Vila, Vanuatu
}

Les relations familiales en ville sont brokbrok : partage de nourriture et contribution à Port-Vila, Vanuatu

\section{Daniela Kraemer}

\section{OpenEdition}

\section{Journals}

Electronic version

URL: http://journals.openedition.org/jso/7850

DOI: $10.4000 /$ jso. 7850

ISSN: $1760-7256$

\section{Publisher}

Société des océanistes

\section{Printed version}

Date of publication: 15 December 2017

Number of pages: 105-116

ISSN: 0300-953x

\section{Electronic reference}

Daniela Kraemer, "Family relationships in town are brokbrok: Food sharing and "contribution" in Port Vila, Vanuatu", Journal de la Société des Océanistes [Online], 144-145| 2017, Online since 15 December 2019, connection on 15 March 2021. URL: http://journals.openedition.org/jso/7850 ; DOI: https:// doi.org/10.4000/jso.7850

This text was automatically generated on 15 March 2021.

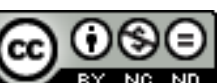

Journal de la société des océanistes est mis à disposition selon les termes de la Licence Creative Commons Attribution - Pas d'Utilisation Commerciale - Pas de Modification 4.0 International. 


\title{
Family relationships in town are brokbrok: Food sharing and "contribution" in Port Vila, Vanuatu
}

\author{
Les relations familiales en ville sont brokbrok : partage de nourriture et \\ contribution à Port-Vila, Vanuatu
}

Daniela Kraemer

1 In Freswota, a residential community of Port Vila, the capital of Vanuatu, young men often mentioned the "empty saucepan". As seen in Luke's words above, the empty saucepan is an idiom they use to reflect some of the social problems they experience in urban Vanuatu today; high cost of living, alienation from access to agricultural land, high rates of unemployment, and financial insecurity. Yet, in the context of Freswota, the empty saucepan also speaks to specific concerns surrounding shifts in family relationships, often produced and maintained through a system of sharing of food. In Freswota, as in much of Port Vila, families face difficulties balancing their incomes with obligations to give and receive. As such, some urban families are increasingly excluding people, those who are seen as consuming without contributing, from eating their food.

2 This article examines why many Freswota young men frequently mention the "empty saucepan". It is through an exploration of the empty saucepan, that some of the contemporary shifts emerging in Port Vila become more visible. After a description of Freswota community and the young men who are the subject of this research, the article considers some of the constraints of urban living, what influence the emic notion of "contribution", in a context of neo-liberal capitalism, is having on intergenerational relationships, and what other relationships are developing. Ultimately, this article suggests that urban unemployed young men are increasingly experiencing their parents and other family members as unsupportive, and as such, other relationships in their community are becoming stronger. 


\section{The Freswota squad of boys}

3 Luke is one of about 60 young men who see themselves as members of the Freswota "squad" (skwad) of "boys". "Boys" is how men who practice the life of the "young man" are referred to by the wider community. Thus even though some of the young men I spent time with were in their mid and even late twenties, because they spend their time with the squad, doing squad activities, they continue to be characterized as part of the "boys". As my doctoral research predominantly focused on this group of young men, I talk about the young women of Freswota only when it relates to the young men, or when talking about social relationships between the genders (see Kraemer, 2015).

4 "Squad" refers to any group of peers (usually single sex) who assemble regularly together. In Vanuatu, the term 'squad' refers to a sports team (Crowley, 2011) and residents of Freswota believe the first Port Vila "squad" was the Freswota boy's football team. Today, 'squad' is used casually to mean a group of friends, as with one of my friends who often spoke about eating lunch at school with her 'squad of girls' (skwad blo ol gel), or another group of boys who met regularly to drink kava and called themselves the 'squad of boys of Dog Street' (skwad blo ol boe blo Dog Street). While some squads of boys are informal, others, such as the squad of boys I spent time with, are more cohesive. As I suggest elsewhere, the 'squad' is emerging as a new informal infrastructure or 'modality of social organisation' for young people navigating a precarious urban context (2017b). In Vanuatu the term 'gang' is not often used to describe such groups of boys since 'gang' has a popular connotation of organised violence and crime. Furthermore, these groups are rarely refered to as 'rascals' (raskol), the label given to groups of young men in Port Moresby who are involved in criminal activities such as theft, burglary and street crime. While some boys in some squads do steal and can be violent, individuals or small numbers of boys usually carry out these acts. Port Vila squads thus differ from the 'rascals' of Port Moresby who are described as gang networks involved in extensive organised criminal behaviour (Goddard, 2005: 82).

5 Like most of the young men I came to know, Luke who I quote above, was born in Port Vila and as a young child, in the 1980s, moved to Freswota with his family. In the late 1970s and early 1980s, Freswota was being developed by the Vanuatu Housing Corporation to accommodate the significant rural to urban migration occurring around the time of Independence in 1980. Families, who could afford it, purchased Freswota plots of land. They built makeshift shelters, or turned the land into small agricultural gardens while they rented elsewhere and saved money to build a house.

Map 1. - Localization of the Freswota residential community of Port Vila

Freswota is in the red circle

Journal de la Société des Océanistes, 144-145 | 2017 


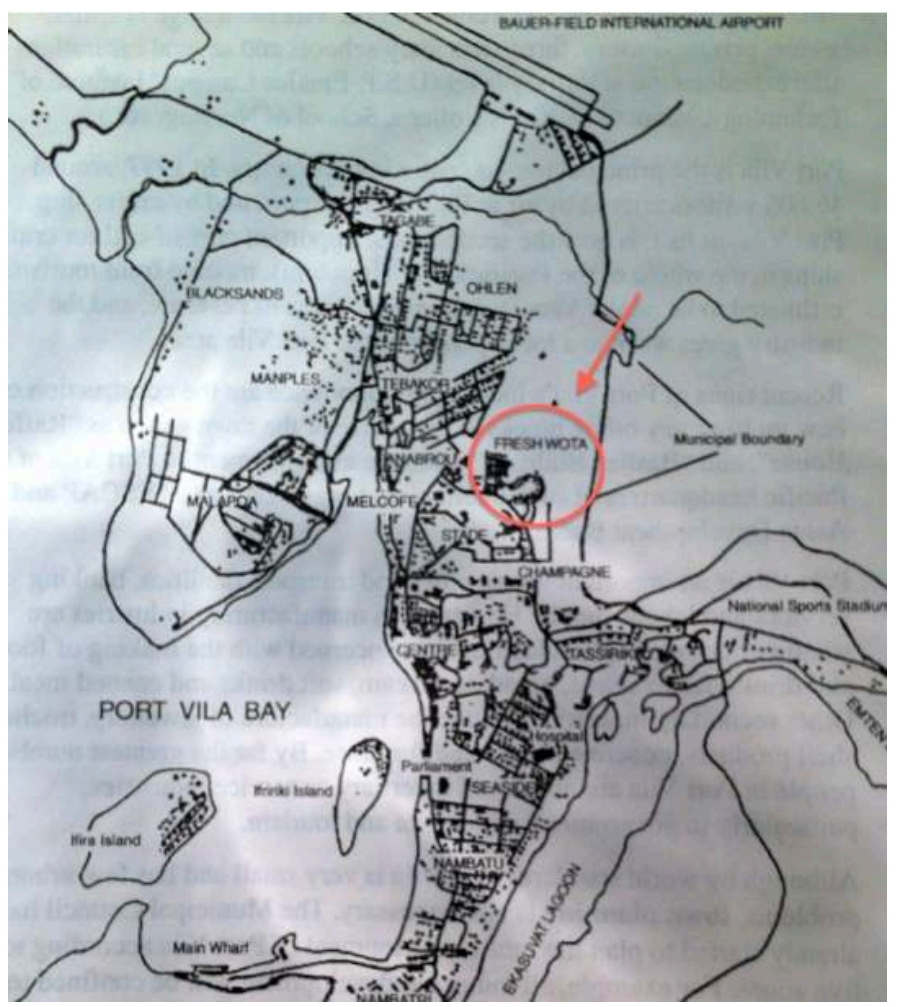

(๔ Vanuatu Dept. of Education, 2000)

Freswota is located on the northeast side of the centre of Port Vila town and has an estimated 5,000 residents. When I lived in Freswota, some 30 years after the first bulldozer began clearing the land, it was still in the midst of big development. Families who had purchased their plots of land in the late 1970s and 1980s, like Luke's parents, through hard work and innovation, finally had enough income to develop their property. During my time in Freswota these families were renovating their houses; indoor kitchens were being built, second stories added on, and smaller 'rental units' were being constructed for supplementary income. Elsewhere in the community, roads were getting paved and electricity and water pipes were being installed at the community's boundaries where the last plots of Freswota land were being sold.

In 2008, Freswota was the community you wanted to live in. Other Port Vila residents generally admired Freswota as a "good" community, perceiving it to be "organized" and "cooperative" (Kraemer, 2017b). ${ }^{1}$ Many people also admire Freswota for being "a mixed island community"; there are few households in Freswota organized around island and village of origins. Freswota residents perceive the community to have originated as a "virtual-no-place" (Kraemer, 2013). In Freswota mythology, the first people living in the community had little shared social meaning. Shared social meaning has developed over time, as the young men who are the subject of this research, have actively engaged, through their community work and setting up of the Freswota councils, in bringing Freswota residents with no prior shared history into a context of shared meaning and greater relationship (Kraemer, 2013, 2017b).

When I spent time with Luke and his peers, from 2008-2010, their ages ranged from 16-28. As they were all born and raised in town, their lived experience is different from that of their parents or grandparents, most having migrated to town from smaller rural islands. Few of the young men I knew had ever visited their parents' ancestral home 
island(s) (Kraemer, 2013) due to high cost of transportation and as circular migration gave way to urban settlement (Bedford, 1977). The generation of youth I worked with have had little opportunity to spend time with extended family members, learn their parents' home-island languages, custom and culture (kastom), or become familiar with their ancestral lands. As such, for this generation of urban born youth, their relationship with their ancestral places and the people of their places is greatly diminished (Kraemer, 2013).

However, while they might not know their ancestral places, many urban youth do have ties with the rural islands - either through nostalgic story-telling, idealization, viewing popular string-band videos filmed on rural island locations, or visiting islands in the archipelago as part of organized trips for political party getaways, theatre troupe tours, hip-hop troupe tours, or sporting tournaments. Freswota youth are familiar with the rural islands, just not with the islands of their predecessors.

Young people have grown up speaking Bislama, their native tongue, and live in a context of cultural and ethnic diversity previously unprecedented in this part of the world. Unlike their predecessors, Freswota youth identify themselves as "man town" or "man Freswota", rather than "man Malakula" or "man Tanna", for example. For them, the important question, and the one they frequently ask and answer when they meet other youth, is not "where are you from?" but "where do you sleep?" For them, it is increasingly more relevant and informative to know that someone sleeps at or grew up at the "Dark Corner" of Freswota-4, than knowing a person's island heritage or heritages (Kraemer, 2013: 25).

Photo 1. - Freswota Squad of boys spending the time in one of their shelters at the end of the road of the community of Freswota, 2013

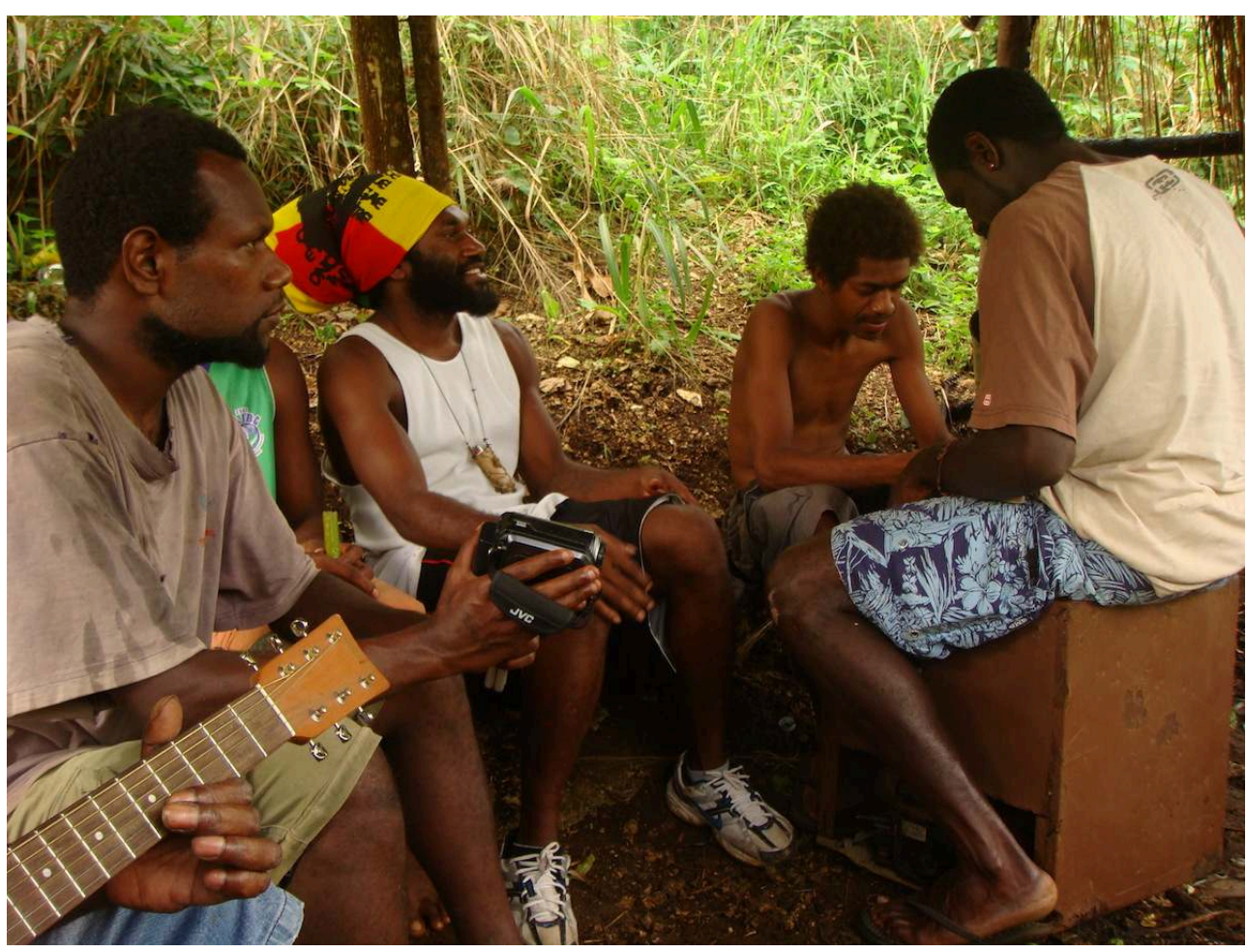

(๔ Daniela Kraemer) 
11 When I lived in Freswota, Luke and his peers spent every day gathered together - on the back roads of the community, in abandoned sheds, behind a particular grocery store, in the football field, in empty kava bars, any place they could find. There they spent mornings reading the newspaper, catching up on news of the community, playing cards, and sharing their first joint of the day (the members of this particular squad of boys smoked marijuana). As the morning progressed, they would confirm their plans for the day. These often included a mix of community work such as attending council meetings, organizing fundraisers and community-wide events like bike relays or Independence day celebrations; group tasks such as buying or selling marijuana, visiting someone in another community; and extra-curricular activities like practicing music or sports. From time to time the squad is hired for paid work such as building / repairing shelters for the Freswota food market, cutting grasses for the Municipality and working as security for Port Vila's special events.

While the public perception is that these young men just "hang around" on the roads, I experienced a group of young men busy and focused on "planting roots" in the community (Kraemer, 2013) and overcoming obstacles to their living a "successful" urban life. Yet, many people throughout Port Vila refer to these groups of boys (groups like this are found throughout the town) derogatively as "boys of the road" (boe blong rod). This phrase has multiple meanings. Firstly, saying a boy is a 'boy of the road' implies that the boy has no father. This relates to the second meaning where being of the road also implies that a person is not of a place (man ples) and thus moves purposelessly in an unproductive and un-reproductive condition. Lastly, in Vanuatu, time spent on roads is usually in the form of travelling and is directed and with intention. People in Vanuatu disapprove of "unmotivated movements" (Jolly, 1999: 284 ; Taylor, 2008a : 136), and therefore the boys' hanging around seemingly doing nothing is highly criticized.

13 For many people, this aimlessness and unproductiveness is scary. Moreover, people fear that the young men's actions are undisciplined and unrestrained. When faced with having to walk past a group, many people, men and women, will cross to the other side of the road, or will take a different route home. Indeed, I learned months after leaving the field that concerned community members asked each other :

"where are her parents? Do they know she is walking around with this dangerous gang?"

14 While it is true that Freswota can be a violent place, and that these young men are at times part of this violence, the point of my work with these young men is to further our understanding of their lived experience and to unpack the context that has created these large groups of young men hanging out day after day.

\section{Constraints of urban living}

15 I first learned that food was sometimes not being shared between family members in a household one afternoon when my companion that day, Robert age 27 (who I had met outside of Freswota and who was not a member of the Freswota squad of boys), asked whether we could stop by his house on the way into town. While waiting for him outside, I heard a man's voice exclaim:

"Good you are leaving." 
When Robert came outside he was upset. He explained that it was lunchtime and his mother had just started handing out dishes of food. Robert told me that his uncle was visiting from another community and brought the food items they cooked for lunch with him. Robert said it was likely that his uncle did not want to share food with Robert because Robert had not contributed to the meal. Since Robert is a young man with a job, who contributes to his family, he was upset by his uncle's response.

Photo 2. The parents of the young people of Freswota believe, that by going to live in town, they would assure a better life their children; but, with the limits of the schooling and little of opportunities for real jobs, many urban young men spend their days with their squad by the roadside by wondering about the choice made by their parents, 2013

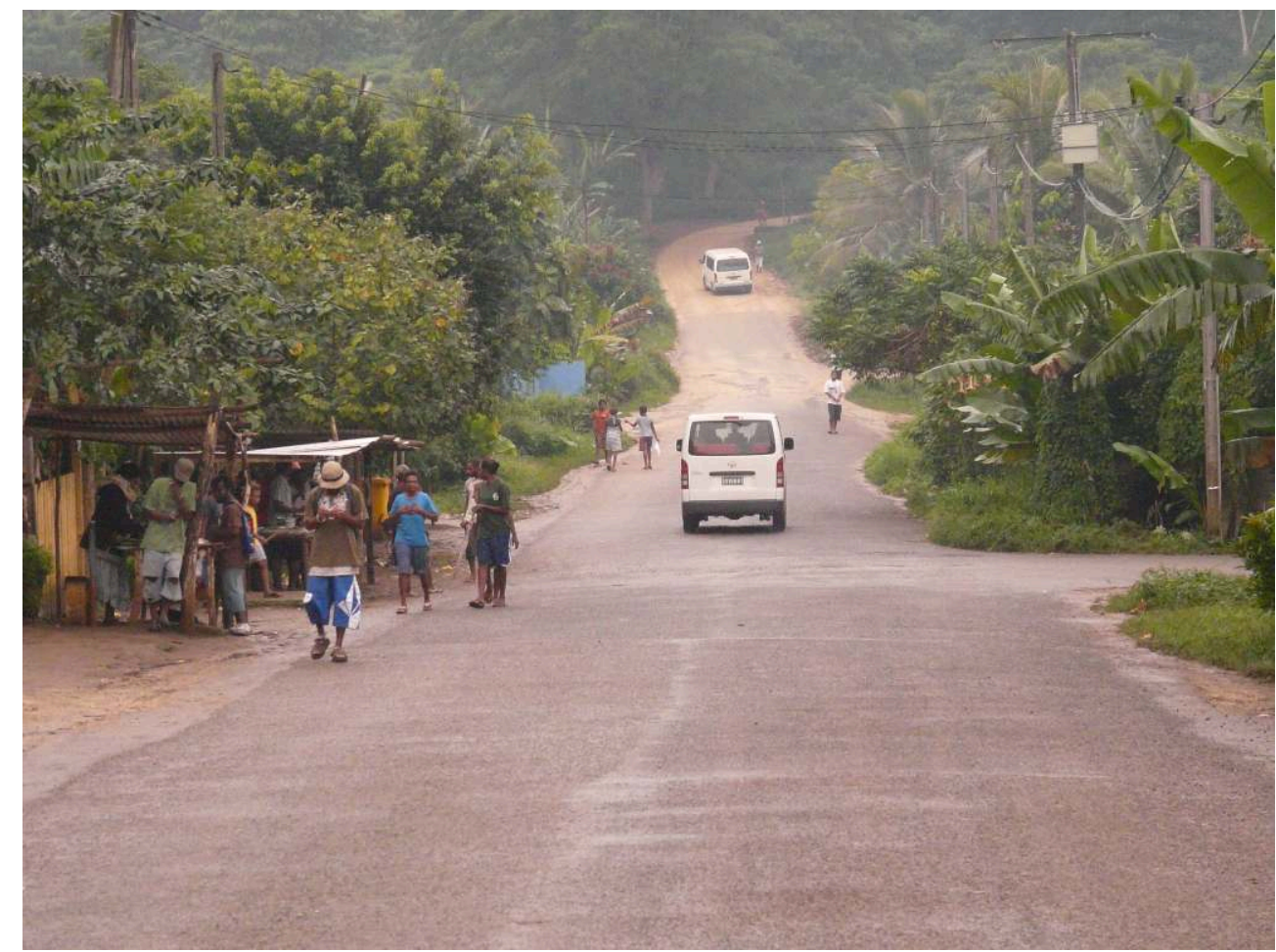

(๔ Daniela Kraemer)

17 Is it surprising that Robert's uncle reacted this way? Perhaps his response reflected the relationships and dynamics that he has with the young men in his own household. Increasingly in Port Vila, households do not have sufficient income to feed the number of people in them. In Freswota, the typical household includes a married couple, in their early to mid 40s, the couple's three or four children, and then a combination of one of the children's partners and their babies, or one of the couple's siblings, or one of the couple's siblings' children (a nephew or niece). While the Vanuatu National census reports the average household size of Port Vila to be 4.8 (Vanuatu National Statistics Office, 2009), my own household survey in Freswota, put this number closer to 6.3.

The parents earn the majority of the household income. They work as teachers, office workers, managers of construction companies, small business owners and government and NGO employees. Many also supplement their household income by renting out small houses or rooms, buying taxis and buses that family members drive on their behalf, or by running kava bars or small shops out of their homes (see photo 3 and Rio, this issue: 96). These families are part of Port Vila's growing urban middle-class. 
Photo 3. - Petit magasin de proximité dans le quartier de Freswota, 2013

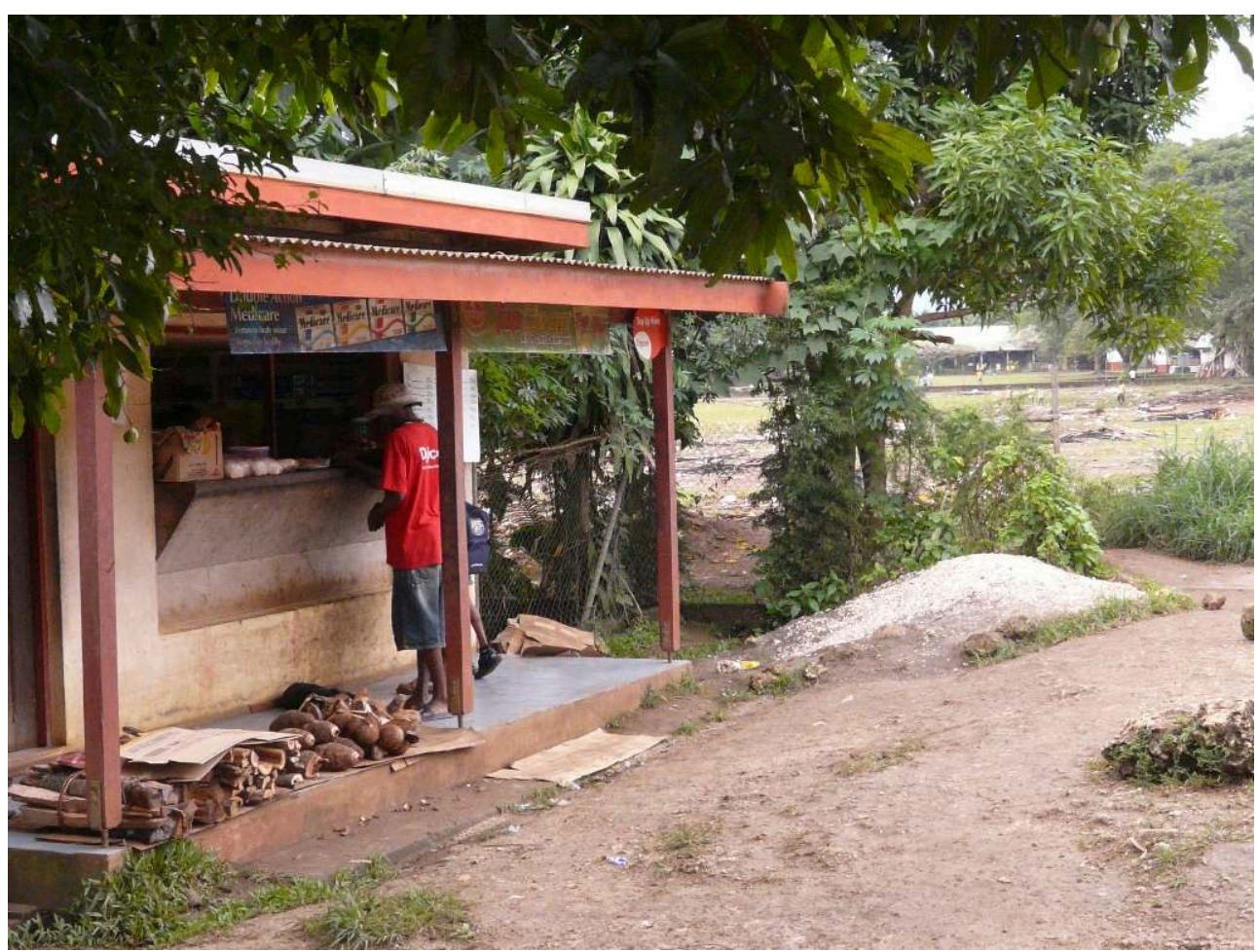

(๔ Daniela Kraemer) households usually let the unemployed young men sleep in their house, this is increasingly becoming problematic, as houses are over-subscribed. For example, Griffith, age 23, slept each night in an unfinished rent house. He said he slept on an old mattress there because there was no space for him in his sister's home. I also know that 28-year-old Arthur, regularly slept in one of the "ghettos" - the abandoned sheds that the squad of boys I worked with used as a clubhouse, as he said his parents' house could no longer accommodate him.

What is occurring in these urban households for some family members to deny their young men places to sleep and food? Many of the urban young men I spent time with experience a real lack of opportunity that has been many years in the making. While the years following independence were a time of hopefulness for people in Port Vila, as people dreamed of prosperity and opportunity in town, the reality did not match up (Bolton, 1999; MacClancy, 1980). This is particularly true for the generation of young people born just after Independence. Sending their children to school became increasingly unaffordable for Vila families, ${ }^{2}$ and so many of this generation were not able to complete more than a year six (grade six) education. As 23 year old Jaksil told me:

'It is the parents' responsibility to pay the school fees of their children. But if they don't, like with me, well then what has happened is that I don't have a certificate or piece of paper or anything to prove that I can work. So even if there is a chance to work out there, I can't even go and apply. It is the problem of the system because here in town education is the only road that will let you go inside the system. But when you don't have education, when you don't have that paper, then what do you do? The product I need to live in town is money, but I can't get it, I am a school- 
leaver, I only have a small education. In town there is only one road to win money and I had to leave that road halfway.'

The young men I knew expressed a desire to be understanding and forgiving of their parents' previous inability to pay their school fees. However, on the days when their stomachs were particularly empty, they criticized their parents for having made bad decisions in how they had spent their money. As Jacksil mentioned above, these young men refer to themselves as "school-leavers" and "school drop-outs". Not-having sufficient formal education has greatly impacted their sense of identity. As Owen, age 24, said:

"Our parents thought that they were giving us a good standard of life here. They thought that we would have a chance to grab this system in town. We believed that we too would get a chance to contribute to this society, to work, to contribute to this life here, but then we look, and well, we have only a little education, and we have no jobs, and so at the end of the day here we are doing nothing at all. Really, us boys of the road we don't have a chance. We depend on the system. We need work to have money but we can't get work. So life is very hard. It is very hard especially if you want to start a family in the right way, to start your own life and you don't have anything to start it with."

Here Owen speaks of the boys' general experience of being marginalized from urban systems, which they see as the means through which urban living and their future depends. While most of the squad of boys are fathers themselves, none of them are married, and few have been able to establish their own households and feel they are hindered from transitioning from youth to the status of adult. ${ }^{3}$ When the boys spoke about their future, they often talked about their future as a 'question mark' (kwestin mak) implying that there is no knowledge about what their future will bring.

Participation in the wage labour economy has always been a central aspect of Port Vila's history and development. During the colonial period employment was a precondition for ni-Vanuatu to be in town, an idea that Mitchell observes has continued to inform perceptions about life in town today, illustrated by regular suggestions that unemployed youth be sent back to their home islands (2004: 361). Yet, high levels of unemployment make finding work challenging, especially for young men without high school diplomas. According to the last census, in urban Vanuatu (Port Vila and Luganville), the unemployment rate is $12 \%$ (Vanuatu National Statistics, 2009). Urban young people experience a significant tension between social expectations that they work, their limited education, and the high levels of unemployment in town.

Most of the young men I knew expressed sincere desire to work. They want to earn money and to contribute to their families and households. Yet, another barrier to their ability to do so is a decline, since Independence, in the availability of untrained jobs in Vanuatu. As the 70 year old father of the owner of a popular kava bar in Freswota, explained:

"Before, in the 1950s and 1960s very few people went to school but many people were employed in what we called unskilled labour. The main work at that time in the islands was cutting copra and the main work at that time in town was loading and unloading the copra into containers onto ships. Gone are the days of plantations on the islands, so everyone goes to town to find work. But in town there are no unskilled jobs. Before, lots of people also worked on barges to help move the goods. This gave work to plenty of the youth and the pay was good too. But today to get a job on a barge requires a school paper, and today the barges don't employ a lot of people because they use machines to move the things around. So this is a 
problem for the youth in town today. Especially those who are age 30 who are stuck in between who don't have the paper."

relationships with extended family on their parent's home-islands, family on the islands are increasingly obstructing urban youth from ceremonies that give them access to ancestral land. The local term used in town and on the islands to describe this phenomenon is "hiding ground" (stap haedem graon). It refers specifically to not sharing the knowledge of the roots or lineage connected to the land, which is the basis upon which claims are made. Based on the time I spent on the islands, I observed that people are hiding land from their urban relatives because in today's increasingly expensive world, land is being perceived as a valuable commodity as well as a finite resource that some islanders want to develop unshared rights to. Indeed, only one of the young men I knew told me that when his grandfather died, his father paid for him to go to the home island to present gifts of food at the ceremony and to kill a pig in order to continue their family's rights to access the land. In contrast, all the other young men I knew were either not given the opportunity to make such a ceremonial payment, did not know when such ceremonies were occurring, or could not afford to contribute to or attend them. As Rodman has noted for South East Ambae, failing to give gifts and to participate in rituals, paves the way for someone else to do so and to claim access to the land (1987: 44). Diminished access to land further disenfranchises urban youth. Not only does this urban generation not have the high school certificates that are the current minimum requirement for formal employment in town, and a reduction of the availability of unskilled jobs, they also do not have access to a valuable resource that through agricultural work or other investments would enable them to help support their families.

What all of this amounts to is a generation of urban youth unable to contribute money or food items to their households and families in town. For example, when 24-year-old Hudson heard about his paternal grandfather's death he was visibly distraught. He said 
he neither had the money to purchase the 5-kilo bag of rice he said he needed to give to his father and his family, nor the 200 Vatu (\$2.00AUS) bus fare he needed to make the trip to his grandfather's house. As a result, he did not participate in this important ceremonial ritual. Lack of money was also the reason Samuel, age 26, said he was delaying visiting his sister and her new baby. He told me that he did not have money to purchase, nor land to grow the food items he was expected to give to celebrate the child's birth. When Samuel told me about this problem it had already been two months since the baby was born. Generally, unemployed young people in Freswota do not have the means with which to contribute to these important ceremonies and so tend to, like Hudson and Samuel, not participate in them.

Literature on Vanuatu demonstrates how the giving of gifts is an important practice through which Vanuatu social relationships are produced and reproduced (Rodman, 1987; Jolly, 1994). Through a system of giving, people become joined in permanent and enduring relationships. That many young people in Freswota are not giving to family both in the every day and during important kastom ceremonies, is part of the broader problem experienced by young people born and raised in town - where parents have been making choices for young people's futures that exclude them from participating in this exchange. A consequence of this lack of "contribution" on behalf of unemployed young men, is a diminishment in the number of family members who will offer resources and support to them.

\section{Contribution}

Central to understanding what is currently occurring in terms of sharing of resources between family members in Freswota is the local notion of "contribution" (kontribiut), a term which has come up in several of the young men's quotes above. People in Freswota use the term "contribute" frequently when describing the manner in which they or others participate in society. Specifically, the term is used to refer to someone's individual participation in a collective endeavor. Freswota residents remark about what people contribute to the church, or to wedding ceremonies, women complain about husbands who do not contribute enough of their paycheck to their households, and neighbors talk about households that do not contribute to community fundraisings.

31 The idea of contribution is not just about giving money or food items, but can be about contributing one's labor as well. For example, when Manu, age 28, arrived unannounced at my house during a meal I was preparing with some of the young men, he responded with confusion when I gave him a plate of food. He told me that he did not deserve to eat this food because he had not contributed anything to the meal. Unemployed young men experience significant tensions pertaining to their status and presence in the household. They often talked about family conflicts regarding whether they, unemployed young men, who are seen as not "contributing" to the household, should be given food. Twenty-two-year-old Benny told me, for instance, that he is one of the few boys in the "squad" whose parents give him food every day, and a few coins each week. He explained that this is because every morning he sweeps and mops the floor. Benny said that his parents ask him to do these tasks because he has no sisters living in the house.

However, unlike Benny, most of the young men I spent time with told me that they do not contribute to the households in which they live, neither financially nor through 
labour, and so they accept that often when they return to their houses there is no food in the saucepan and so they "don't always eat". A parent of one of the young men offered the income earner's perspective. He said:

"a parent will never tell a child to leave the house and not come back. No! Children are like your right hand, they are very important. But parents will not give food to boys who are not working because they want them to work for the food they eat. Parents believe that it is not fair that others work and they eat for free."

The young men described this as a 'Catch-22'. Many said they would contribute to their families if they could, but the barriers described above make it difficult for them to do so. Even contributing labour to the household is difficult for these young men as the family's non-formally employed young women do the majority of the household work and childcare. When I spent time with women, the denial of food by their parents never came up as a topic of discussion. Moreover, I did not find that parents encouraged their young women to spend time outside the house (quite the opposite). In terms of support from their parents and household, the experience of unemployed "girls" contrasts that of unemployed boys. The gendered nature of the saucepan is important to point out.

The focus on contribution, or its lack thereof, explains Luke's comment, with which this paper began - that parents do not always share food with children like him. Freswota families often talked about planning for their retirement in town. Many parents told me that they worry about who will support their urban living in their old age. Like in many places, they see their children as an investment for this future. Yet, as the cost of urban living increases, and as their children are unable to "contribute", families are becoming more discerning about which children to invest in. For some families, providing resources to another young person with more successful education or employment prospects, and thus a higher chance of a return of their investment, is more inviting than supporting their undereducated and underemployed sons.

In Freswota, sharing food between members of the same household seems to be increasingly restrained. The practice of hiding food from others is not a new occurrence in Vanuatu, and throughout Melanesia food sharing and food hiding has always been a way social relationships are modulated (Kahn, 1986; Munn, 1986: 50). Yet, in Freswota, the practice of not-sharing food with their sons is increasingly widespread. This is transforming family relationships in town. Following colonization and the introduction of Christianity, urbanization is emerging as a process of tremendous social and cultural change. As Jaksil explains:

"In town relationships are broken. Some families in town build big walls around their houses and ignore their poorer family members especially ones like me uneducated boys of the road. This not sharing happens a lot and this is not right because if they are successful they should be open to every man, especially towards their family - this is what family in Melanesia is about."

Jaksil correctly points out that resources are not circulating the same way as before and so not everyone has the opportunity to participate in a system of social relations produced through debts and obligations to give and receive. The emic notion of "contribution", in an increasing context of neo-liberal capitalism, is transforming inter-generational relationships throughout Port Vila. 


\section{Non-family relationships in town are becoming stronger}

37 As I have been describing, the relationship between many of the young men I knew, and their parents and other members of their households, is increasingly unsupportive, as young men are unable to rely on them for social and economic support. Bloch writes that

"eating together is not a mere reflection of common substance, but a mechanism that creates it" (2005: 53).

By not sharing food with the young men, and additionally excluding them from being in the house to join during meal times, the strength of the bond between family members in a household is transforming.

How are young men coping with the refusal of their family to offer support? By focusing on developing more supportive relationships with friends, neighbors and other community members. For example, in Freswota, the "squad" has become a mode of social organization; an informal infrastructure unemployed young men have developed to broaden their social networks and order their social life as they try to manage a context of unsupportive living (Kraemer, 2013, 2017b). The squad leaders provide squad members with the structure and meaning that they say is important in their lives. Indeed Eugene, the squad leader, was always referred to as "Sargent", the "sergeant major" because he was seen as the director of the group. Squad leaders guide the group in their daily activities (community work, local political action etc); they provide discipline (such as when one young man, drunk, spent a night unsafely at the side of the road and a squad leader prohibited him from drinking for two months); and offer support and representation to squad members (for example during reconciliation meetings or dispute hearings). More relevant to this conversation about food sharing, is that the squad leaders also regularly purchased food, like chicken wings and rice, for the squad to cook. The squad regularly eats lunch together in whatever abandoned shed they are spending their morning in. While in 2010 hunger was not part of a wider discourse in Port Vila, among unemployed young men it is a significant problem. Aware that the "saucepans" are often empty, the squad leaders try to provide food for squad members regularly.

Food items were always purchased by squad leaders with money earned from the work the squad does for the community such as cutting grass, fixing shelters, cleaning up plots of land, moving brush etc., and from their own initiatives such as their marijuana cooperative and their community car wash. The leaders of the squad also have relationships with local politicians and on occasion the group earns money by formally working for the municipality, cutting the grass along the major roads and working as security guards for Port Vila events. After each time the squad worked, Sargent would distribute payment to the boys who had helped. In addition, he would pay the kava that night for many members of the squad. Sargent's role was very much as patron, a word they often used to describe him. In this way we see that the squad, not family, have become the means through which unemployed young men navigate both their inability to secure formal employment and a regular income, and their not having enough food to eat. 
41 Not surprisingly, the squad members also employ the concept of "contribution" in their relationships. While Sargent and the squad leaders provide their leadership and support to members of the squad, members of the squad also contribute their labour and time. As well, they share with each other desired items whenever they gain access to them. For example, when Bryson, age 18 got his hands on a bottle of whisky, he sought out Sargent and several other key boys and invited them to share it, even though it was 9 in the morning. In contrast, when one young man hid a bag of marijuana from the group, members of the group tracked him down and punched him. For these young men, like their parents, the sharing of food and other comestible items is an important medium through which they develop supportive relationships with one another. As such they also spend much of their time and energy focused on how alcohol, kava, cigarettes and items for lunch are acquired and shared (Kraemer, 2013).

The question that comes to mind is why are young men not contributing the money they access to their families? Similar to the reasons these same young men choose to spend the money they acquire on mobile phone credit (Kraemer, 2017), unemployed urban young men, spend the few coins they have on food and kava to share with their friends and fellow Freswota community members, as this maximizes the items they have in creating and maintaining supportive relationships. We see that the sharing of items continues to be an important means through which social relationships are produced and reproduced in Freswota, it is just that now for unemployed urban young men who experience diminished support from their parents and other family members, their solidarity with "non-family" in Freswota is becoming stronger.

The language they use when referring to Freswota friends reveals the shift in strength of bonds. For example, when referring to Freswota friends, young people use the terms "brother" and "sister". Furthermore, during Freswota public events, they refer to the community as the "Freswota family". Increasingly it is the Freswota family, and their Freswota brothers and sisters, who offer more financial and social support and who share in the same experience. The language reflects this. Indeed they draw a sharp distinction between their Freswota family, Freswota sisters and brothers and their parents, actual siblings and other relatives. They do this by adding the adjective stret, whenever talking about an actual family member. They say for example "they are my stret family". The adjective stret, is translated into English as "correct", "real", and more appropriately "directly related" (Crowley, 2011, 1995: 235). In contrast, they refer to one their Freswota friends just as "brother" or "sister" without the adjective. I believe this terminology reflects the tensions I have been discussing surrounding people's obligation to give and receive. Friends and community members who share and are supportive are now considered "family", while those who do not, even though they might be related by blood or marriage, are considered "correct family" or just one's "relations".

\section{Conclusion: a shift in solidarity}

44 For the parents and contributing members of a household, sharing or not sharing of food has become a sign of judgement as the relationships between members of a household are changing. The "big walls" that Jaksil refers to in his words above, suggest that a new urban household composition is emerging, one in which membership is based on who can contribute and who cannot. This explains why many Freswota 
households include one of the parent's employed nephews and siblings, while increasingly excluding unemployed sons. Jaksil's words above emphasize this point walls (physical and symbolic) are being built around poorer family members like him.

It often struck me that the unemployed young men held an implicit assumption that they were entitled to their parent's resources. This entitlement reflects the tensions I have been addressing in this paper surrounding consuming, sharing and the notion of "contribution". The conflict centers on an increasing discrepancy between ideal family relationships and practiced relationships, and a growing tension in attitude about sharing between people who have, and people who have not.

In Melanesia, public acts of not-sharing have often been stigmatized in such a way that people shared out of fear of recrimination, such as from witches who kill people who act selfishly (Whitehead, 2000; Munn, 1986). Yet in Port Vila today, the etiquette and attitude towards sharing with family is transforming, and what is emerging is a refashioning of the notion of reciprocal giving in a way that emphasizes individual contribution. While throughout Vanuatu a process of reciprocal gift giving often works to create enduring social relationships, the contemporary urban interpretation of "contribution" creates social distance instead. This is because reciprocity concerns the interplay between giving and receiving, which can span generations, while "contribution" focuses more on the capacity an individual person has to give in an economic environment where accessing money (and through it, food) is unequal and difficult. Furthermore, while sharing food and giving gifts was once more a collective effort, as food was collectively produced, shared or consumed, in Freswota, the sharing that is based on "contribution" is dictated by individuals, and pertains to individual contributions. This was seen in the example with Robert and his uncle. In the urban context, new kinds of distinctions and values are emerging.

It is important to note that reciprocity is not diminished. Rather, what is emerging is a social context in which the people who cannot contribute are being marginalized from the system of contribution all together. The young men with whom I worked often expressed resentment that their families do not share with them. Yet, this more widespread phenomenon of "not sharing" is in actuality the application of Vanuatu principles of reciprocity. Unfortunately, for unemployed young men, they do not have the opportunity to participate in the sharing of their households.

What seems to be occurring in Freswota is a shift from solidarity between actual and close kin, towards a solidarity based on age class, common experience and expectation. As 21 year old Craig said about his best friend Gerome:

49 "This guy is my brother, he is the only person who I trust. When I need something he is there, he would even give me the shirt off his back. Gerome is my brother, he is my family. You ask about my stret family? Well, I don't know. My stret-family they don't really help me."

For the young men I spent time with, there is clearly a diminishment in the strength, reliability and also importance of family relations in Freswota. In contrast, it is their squad, made up of a same age cohort of non related neighbours and friends, equally under-educated and under-employed, who are becoming more supportive figures. It is interesting to point out however that, when the young men say that "relationships in town are broken" (reletinsip lo taon i brokbrok), they do not make explicit that it is their family relationships that they experience as broken, while their other relationships, the 
ones with their peers, are becoming stronger. Perhaps it is that even though their relationships with peers are becoming stronger, these relationships are also experienced as unreliable and so unemployed young men lament a broken system of relations and their continued precarious living.

\section{BIBLIOGRAPHY}

BLOCH Maurice, 2005. Essays on Cultural Transmission, Oxford, Berg.

BOLTON Lissant, 1999. Women, Place and Practice in Vanuatu: a View from Ambae, Oceania 70 (1), pp. 43-55.

CROWLEY Terry 1995. A New Bislama Dictionary, Suva, University of the South Pacific, Pacific Languages Unit.

-, 2011 ( $2^{\text {nd }}$ ed.). A New Bislama Dictionary, Suva, Institute of Pacific Studies.

GODDARD Michael, 2005. The Unseen City: Anthropological Perspectives on Port Moresby, Canberra, Pandanus Books.

JOLLY Margaret, 1994. Women of the Place: Kastom, Colonialism and Gender in Vanuatu, Reading, Harwood Academic Publishers.

-, 1999. Another Time, Another Place, Oceania 69, pp. 282-299.

KAHN Myriam, 1986. Always Hungry, Never Greedy: Food and the Expression of Gender in a Melanesian Society, Cambridge, Cambridge University Press.

KRAEMER Daniela, 2013. Planting Roots, Making Place: An Ethnography of Young Men in Port-Vila, Vanuatu, thèse de doctorat, Department of Social Anthropology, London, UK, London School of Economics.

-, 2015. Do You Have a Mobile? Mobile Phone Practices and the Refashioning of Social Relationships in Port-Vila Town, The Australian Journal of Anthropology 28 (1), pp. 39-55.

-, 2017a (à paraître). Working the mobile: Giving and Spending Phone credit in Port-Vila, Vanuatu, in R. Foster and H. Horst (eds), The Moral Economy of Mobile Phones, special issue Australian National University E-Journal.

-, 2017 b. The Port Vila 'Squad' - A Mode Of Urban Social Organization communication présentée dans la sessions Alternative Socialities, organised by Daniela Kraemer and Dominik Schieder, Munich June $29^{\text {th }}$-July $2^{\text {nd }}$.

MILES William F. S., 1999. Bridging Mental Boundaries in a Post-colonial Microcosm: Identity and Development in Vanuatu, Honolulu, University of Hawai'i Press.

MITCHeLL Jean, 2004. "Killing Time" in a Postcolonial town: Young People and Settlements in PortVila, Vanautu, in V. Lockwood (ed.), Globalization and Culture Change in the Pacific Islands, New Jersey, Pearson Education.

-, 2002. Roads, Restlessness and Relationships: An Urban Settlement in Postcolonial Vanuatu, thèse de doctorat, Toronto, York University,Department of Anthropology. 
MUNN Nancy, 1986. The Fame of Gawa: a Symbolic Study of Value Transformation in a Massim Papua New Guinea Society, Cambridge, Cambridge University Press.

MACCLANCY Jeremy, 1980. To Kill a Bird with Two Stones: A Short History of Vanuatu, Port-Vila, Vanuatu Cultural Centre.

RODMAN Margaret, 1987. Masters of Tradition: Consequences of Customary Land Tenure in Longana, Vanuatu, Vancouver, University of British Colombia Press.

VANUATU NATIONAl StATISTICS OfFice, 2009. National Census of Population and Housing, Port-Vila, Ministry of Finance and Economic Management.

WHITEHEAD Harriet, 2000. Food Rules: Hunting, Sharing, and Tabooing Game in Papua New Guinea, Michigan, University of Michigan Press.

\section{NOTES}

1. People were are also quick to talk about the community in less favourable terms, and as I witnessed, Freswota is far from a place without violence, theft, sorcery, dispute, and groups of unemployed young men hanging around at the side of the road

2. Tuition fees for schools, which had been free for French schools and with a small fee for British schools during the colonial period (Miles, 1998: 50) increased after independence, and thus schooling became unaffordable for many families.

3. The only young man I spent time with who lived in his own household with his girlfriend and their 3 babies was able to do so because his girlfriend had a well-paid job.

\section{ABSTRACTS}

Under-educated and under-employed young men in Port Vila, Vanuatu's capital city, frequently refer to the "empty saucepan". This is an idiom they use to reflect some of the social problems experienced in urban Vanuatu today; high cost of living, alienation from access to agricultural land, high rates of unemployment and financial insecurity. Yet the "empty saucepan" also speaks to specific concerns surrounding shifts in family relationships, often produced and maintained through a system of sharing of food. As this paper will show, in Freswota, one of Port Vila's residential communities, families face difficulties balancing their incomes with obligations to give and receive. As such, some urban families are excluding people, those who are seen as consuming without contributing, from eating their food. This article considers some of the constraints of urban living, and what influence the emic notion of "contribution", in a context of neo-liberal capitalism, is having on inter-generational relationships. I argue that urban unemployed young men are increasingly experiencing their parents and families as unsupportive, and as such, other relationships in their community are becoming stronger..

Les jeunes sous-scolarisés et sous-employés de Port-Vila font souvent référence à la « casserole vide » pour refléter les problèmes sociaux rencontrés dans le milieu urbain d'aujourd'hui : coût de la vie élevé, aliénation des terres agricoles, taux de chômage important et insécurité financière. À Freswota, la casserole vide témoigne aussi des changements au niveau des relations 
familiales, souvent générées et maintenues par un système de partage de nourriture. Ici, comme dans la majeure partie de Port-Vila, les familles sont confrontées à la difficulté de trouver un équilibre entre leurs revenus et l'obligation de donner et de recevoir. Des familles urbaines privent ainsi de nourriture certains de leurs membres (vus comme consommant sans produire). Ces contraintes de la vie urbaine et l'influence de la notion émique de "contribution ", dans un contexte de capitalisme néolibéral et de relations intergénérationnelles, font que les jeunes citadins sans emploi voient leur famille comme incapables de les soutenir et, par conséquent, de nouvelles relations au sein de la communauté se renforcent.

\section{INDEX}

Mots-clés: Port-Vila, Vanuatu, jeunesse urbaine, réciprocité, changement social, partage de nourriture, famille urbaine, transformation des relations familiales

Keywords: Port Vila, Vanuatu, urban, youth, reciprocity, social change, food-sharing, urban family, transforming kinship

\section{AUTHOR}

\section{DANIELA KRAEMER}

Université Wilfrid Laurier, Ontario, Canada: danielakraemer@gmail.com 